\title{
Serological relationship of Photobacterium damsela subsp. piscicida isolates (the causative agent of fish pasteurellosis) deter- mined by Western blot analysis using six monoclonal antibodies
}

\author{
Vassilis Bakopoulos, Alexandra Adams, R. H. Richards \\ Institute of Aquaculture, University of Stirling, Stirling FK9 4LA, Scotland, UK
}

\begin{abstract}
Six monoclonal antibodies (MAbs) produced against whole cells of Photobacterium damsela subspecies piscicida were tested against 48 strains of the bacterium from Europe, Japan and the Middle East in a serological study by Western blot analysis. Four of these MAbs (WE14, WE15, WE12 and WE3) reacted with low molecular weight material (of lipopolysacharide nature). These were present in all the strains tested (with only one exception, Japanese strain SP92065) and the only differences noted between strains were of a quantitative nature. MAb VP4, which is directed against a $78 \mathrm{kDa}$ cell protein, also reacted with all strains tested except SP92065. Interestingly, differences in reaction were noted with MAb WE9, which reacts with a range of proteins. These differences were particularly marked between the Japanese and European strains tested.
\end{abstract}

KEY WORDS: Photobacterium damsela subsp. piscicida - Fish pasteurellosis - Serology - Monoclonal antibodies - Western blot

Fish pasteurellosis was first reported in the USA by Snieszko et al. (1964) from an epizootic of white perch Roccus americanus and striped bass Morone saxatilis. Based on phenotypic characteristics the pathogen that was isolated was placed taxonomically in the genus Pasteurella as $P$. piscicida by Janssen \& Surgalla (1968). The disease became very important in Japan, and was first reported in 1970 (Kubota et al. 1970), affecting young yellowtail Seriola quinqueradiata culture. Recently the disease was reported in Europe affecting the marine fish farming of sea bass Dicentrarchus labrax, sea bream Sparus aurata, mullet Mugilidae, turbot Scophthalmus maximus and other marine species (Baudin-Laurencin et al. 1991, Ceschia et al. 1991, Toranzo et al. 1991).

Gauthier et al. (1995) performed DNA homology studies on the pathogen and reported $80 \%$ relatedness with Photobacterium damsela. The authors concluded $P$. piscicida should be placed in the genus Photobacterium as $P h$. damsela subsp. piscicida.
Isolates of the pathogen of various origins have been studied phenotypically. Biochemically, Photobacterium damsela subsp. piscicida has been shown to be uniform with only minor differences derived, mainly, from differences regarding storage and growth in vitro as well as experimental methodology (Janssen \& Surgalla 1968, Kusuda \& Yamaoka 1972, Bakopoulos et al. 1995a). In addition, only quantitative differences were reported when the pathogen was analysed phenotypically (Nomura \& Aoki 1985, Magarinos et al. 1992). Antigenically, Ph. damsela subsp. piscicida has been shown to be similar over wide geographical areas (Magarinos et al. 1992); nevertheless, differences do exist for some isolates at high molecular weights (MW) as was demonstrated in western blot (WB) analysis of the pathogen with polyclonal antibodies (PAb) (Bakopoulos et al. 1995b). Finally, ribotype analysis of the pathogen (Magarinos et al. 1995) suggested the existence of genetic diversity among $P$. piscicida isolates with 3 ribotypes identified. Ribotype 1 represented Spanish and Italian isolates while ribotypes 2 and 3 represented French and Japanese strains, respectively.

Six monoclonal antibodies (MAbs) to Photobacterium damsela subsp. piscicida (hereafter Ph.d.p.) have recently been developed and characterised, and their specificity tested (Bakopoulos et al. 1996). The aim of this study was to use these MAb probes to investigate serological differences between Ph.d.p. strains of different geographical origins.

Materials and methods. Bacteria: 48 Ph.d.p. strains isolated from Greece (31), France (1), Italy (6), Japan (9) and Israel (1) (SA300695, isolated from sea bream in 1995) were used in this study. Their details were provided in Bakopoulos et al. (1996).

Culture conditions. All strains were grown in tryptone soy broth (TSB) with $\mathrm{NaCl}$ at a final concentra- 
tion of $2 \%$ and in the presence of the iron chelator Dipyridyl (Sigma) at a concentration of $0.175 \mathrm{mM}$. Inoculated medium $(25 \mathrm{ml})$ was incubated at $22^{\circ} \mathrm{C}$ in a cooled incubator until satisfactory growth was obtained (48 to $72 \mathrm{~h}$ ).

Bacterial cells were harvested by centrifugation at $3000 \times \mathrm{g}$ for $90 \mathrm{~min}$ at $4^{\circ} \mathrm{C}$. Cells were then washed twice with phosphate-buffered saline (PBS), $\mathrm{pH} 7.2$, and the washed pellet was resuspended in PBS, $\mathrm{pH} 7.2$. The optical density (OD) at $610 \mathrm{~nm}$ was measured and recorded and the suspensions were frozen at $-70^{\circ} \mathrm{C}$ until needed.

Monoclonal antibodies (MAbs): Six MAbs were used in this study, namely, WE9, VP4, WE14, WE15, WE3 and WE12. These MAbs had been previously characterised and their specificity determined (Bakopoulos et al. 1996). The cell lines were grown in Dulbecco's modified Eagle's medium supplemented with 10\% fetal calf serum, Na-pyruvate, L-glutamine and penicillin/streptomycin at $37^{\circ} \mathrm{C}$ and $5 \% \mathrm{CO}_{2}$

Electrophoresis: Calculated volumes of each Ph.d.p. strain suspension in PBS (according to its OD at $610 \mathrm{~nm}$ ) were centrifuged at $11600 \times g$ for $15 \mathrm{~min}$ at room temperature in a microcentrifuge. The bacterial pellet was then resuspended in $200 \mu$ of electrophoresis sample buffer (Nomura \& Aoki 1985) and analysed by SDS PAGE.

Electrophoresis was performed according to the method of Laemmli (1970) on polyacrylamide gels, 12\% separating and $4 \%$ stacking. Samples were boiled for $10 \mathrm{~min}$ prior to electrophoresis and then centrifuged at $11600 \times g$ for $5 \mathrm{~min}$. Gels were run in duplicate, one being stained with Coomassie Blue and the other utilised for $\mathrm{WB}$ analysis. Biorad low range standards were used in the former gel while prestained broad range standards were utilised in the latter gel. Standards were boiled for 3 min prior to application.

Staining: Electrophoresed gels were stained with Coomassie Blue ( $1 \%$ of the dye in methanol:acetic acid:water, $4: 1: 5$, respectively) for $30 \mathrm{~min}$ and then destained until good contrast was achieved.

Western blot analysis with MAbs: The transfer of the electrophoresed Ph.d.p. strains from gels to nitrocellulose paper and the subsequent WB analysis was performed according to the method of Wiens et al. (1990).

Results. Electrophoresis: The electrophoretic analysis of Ph.d.p. whole cells is shown in Fig. 1 for 7 of the strains tested. All 48 strains gave similar electrophoretic patterns. The majority of cell material was evident between 37 and $95 \mathrm{kDa}$. Bands are also evident at lower MW, ranging from 13 to $24 \mathrm{kDa}$. Only minor quantitative differences were noted between strains. In addition, some of the Italian and most of the Japanese strains possessed cell material as a smear at very high MWs (data not shown).

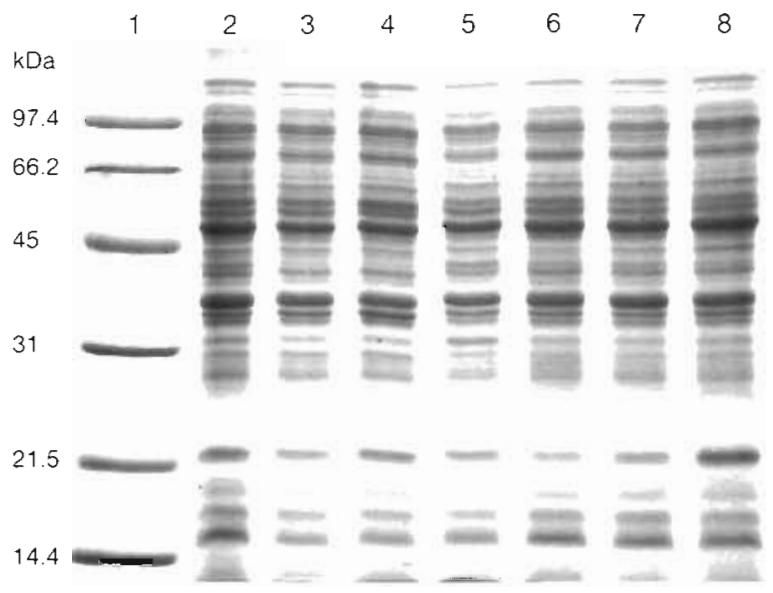

Fig. 1. Electrophoretic analysis of Photobacterium damsela subsp. piscicida. Lane 1: molecular weight standards; 2: PN3; 3: PN510; 4: PN510a; 5: FR10831; 6: 1736; 7: 1746; 8: 11009

Western blot analysis: A representation of the WB analysis of Ph.d.p. whole cells with MAb WE3 is shown in Fig. 2. Both WE3 and WE15 MAbs reacted with material at low MW ranging from 8 to $15 \mathrm{kDa}$. The reaction of the MAbs was similar for all the strains tested and only quantitative differences were noted regarding the $15 \mathrm{kDa}$ material. In addition, the Japanese SP92065 strain seemed to lack the latter material (data not shown).

MAb WE9 reacted with numerous bands, as shown in Fig. 3. The reaction observed in lane 6 (I1210) was obtained for the majority of strains with the $\mathrm{MW}$ ranging from 33 to $213 \mathrm{kDa}$. However, the reaction of MAb WE9 with strains TPF88012 (lane 2), TT90009 (lane 3), I1207 (lane 7), SKP88020, KP9038, SP92144 and to a lesser degree HT90011 (data for the last 4 strains not shown) differed (at high MW) as is evident in Fig. 3. In addition, differences were noted with strains M28561, TPF88012,

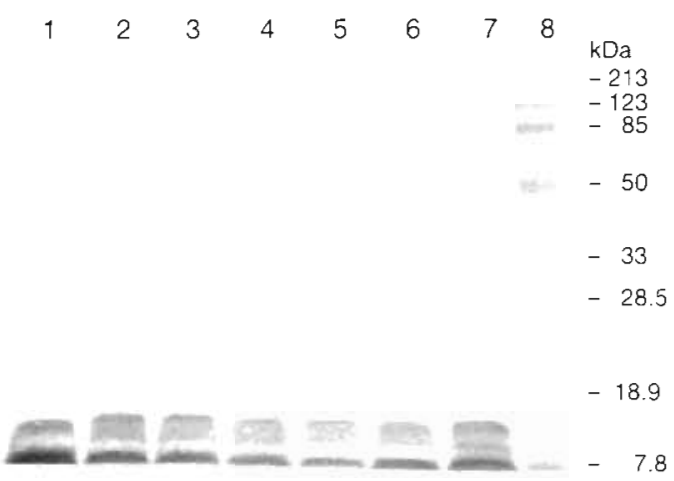

Fig. 2. Western blot analysis of Photobacterium damsela subsp. piscicida with the MAb WE3. Lane 1. THP3; 2: THP1; 3: SEL2; 4: SEL1; 5: N3; 6: K13b; 7: K13a; 8: molecular weight standards 


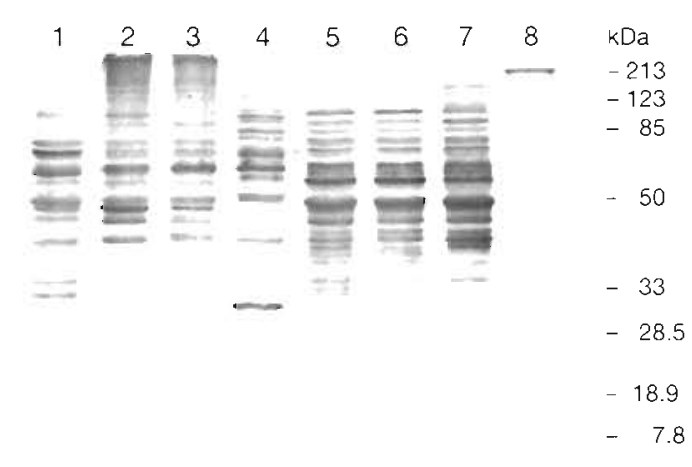

Fig. 3. Western blot analysis of Photobacterium damsela subsp. piscicida with the MAb WE9. I ane 1. M28561; 2: TPF88012; 3: TT90009; 4: SP92065; 5: I1301; 6: 11210; 7. I1207; 8: molecular weight standards

TT90009 and SP92065 (lanes 1 to 4, respectively), where lower reactive material was evident in the MW range of approximately 33 to $50 \mathrm{kDa}$ in comparison with other strains. Strain SP92065 also possessed an additional band at $30 \mathrm{kDa}$ which reacted with MAb WE9 (lane 4).

Fig. 4 shows the WB analysis with MAb VP4, which reacted with 1 band at approximately $78 \mathrm{kDa}$ from all the strains tested except for SP92065.

The reaction of MAb WE12 is shown in Fig. 5. Both WE12 and WE14 MAbs reacted strongly with low MW material ( 8 to $14 \mathrm{kDa}$ ). The same reaction pattern was observed for all the strains tested with only minor quantitative differences. A representative pattern of the reaction with the majority of the strains is shown in lanes 1 to 3. Some quantitative differences were present with some strains (lanes 5 and 6 ).

Discussion. Several methods have been devised to recognise inter- and intra-specific bacterial diversity including electrophoretic, serological and DNA analysis. Davies (1991) was able to identify different Yersinia ruckeri biotypes, serotypes and outer membrane types within serotypes using electrophoretic and serological analysis of isolates of the pathogen of various

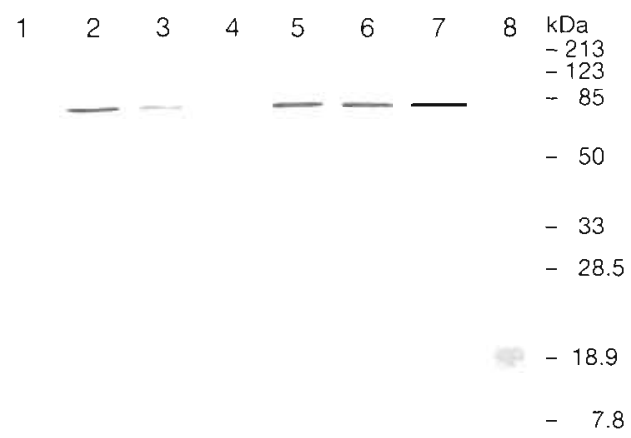

Fig. 4. Western blot analysis of Photobacterium damsela subsp. piscicida with the MAb VP4. Lane 1. M28561; 2: TPF88012; 3: TT90009; 4: SP92065; 5: 11301; 6: I1210; 7: I1207; 8: molecular weight standards

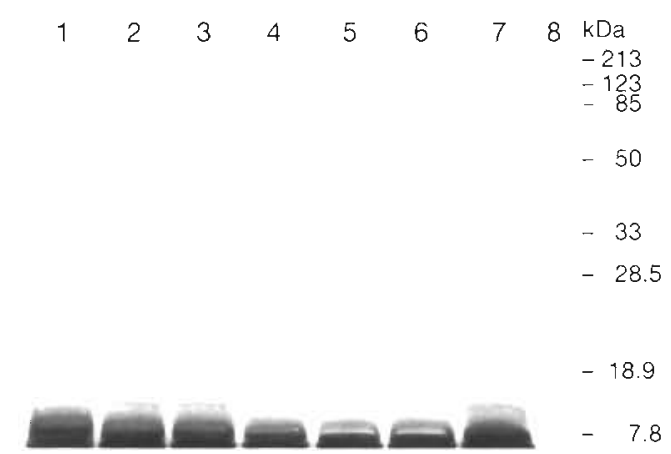

Fig. 5. Western blot analysis of Photobacterium damsela subsp. piscicida with the MAb WE12. Lane 1: THP3; 2: THP1; 3: SEL2; 4: SEL1; 5: N3; 6: K13b; 7: K13a; 8: molecular weight standards

origins, and Zhao \& Aoki (1992), using plasmid profile analysis of Pasteurella piscicida, were able to detect intraspecific qualitative differences. In the present study an electrophoretic-serological (use of MAb probes) approach to identifying Ph.d.p. intraspecific variations was taken.

The electropherogram patterns of Ph.d.p. (Fig. 1) represent the typical whole cell material analysis of the pathogen. Such patterns have been published in previous studies by the authors (Bakopoulos et al. 1995b, 1996), and the differences noted at high MWs for some of the strains were reconfirmed in this study.

Recent studies (Bakopoulos et al. 1996) have also characterised the 6 MAbs utilised in this paper with regard to specificity and antigen binding.

WB analysis of 48 strains of Ph.d.p. with the 6 MAbs showed that 4 of the MAbs (WE3, WE15, WE12, WE14) reacted in a similar manner with all the strains tested, with only minor quantitative differences. Only one Ph.d.p. strain, the Japanese SP92065, reacted differently in comparison with other strains with MAbs WE9, WE3, WE15 and VP4. MAb WE9, however, revealed marked antigenic differences, especially between Japanese and European strains.

MAbs WE3, WE15, WE12 and WE14 are directed against low MW cell material which for WE3 and WE15 was proven to be lipopolysaccharide, and for WE12 and WE14 of either glycolipid or lipoprotein nature (Bakopoulos et al. 1996). MAbs WE3 and WE15 were shown in specificity studies to be specific for Ph.d.p. while MAbs WE12 and WE14 crossreacted with other photobacteria (Bakopoulos et al. 1996). This WE3-, WE15-reacting cell material represents a stable feature of all the Ph.d.p. studied and, therefore, may be a good candidate for vaccine development.

MAb WE9, which has been shown to react with a broad range of genera in specificity studies (Bakopoulos et al. 1996), reacts with a variety of whole cell products from Ph.d.p. The reactive material may represent 
breakdown products of major cell material as well as the presence of a common epitope (the antigen with which WE9 is reacting) on most of the cell proteins ranging from 33 to $200 \mathrm{kDa}$. The antigenic differences which WE9 revealed between Japanese strains (and the Italian (1207) and European strains confirms the genetic diversity among Ph.d.p. suggested by Magarinos et al. (1995), who reported 3 different ribosomal types of the pathogen. Japanese strains were allocated to type 3, Spanish and Italian strains to type 1, and French strains to type 2. Besides the Japanese strains, an Italian strain showed similar differences in the reaction with MAb WE9 when compared with the majority of the Ph.d.p. strains tested and this may suggest that ribotypes or different serotypes of the pathogen can be found among strains of the same origin as a result of an evolutionary process, or that strains from Japan may have entered Europe via fish transfer. An argument in favour of this is that fish photobacteriosis (pasteurellosis) has been an endemic disease in Japan for almost 3 decades (Kubota et al. 1970) while in Europe it was first reported 5 yr ago.

The use of polyclonal antibodies in previous studies (Magarinos et al. 1992) failed to recognise any antigenic differences among Pasteurella piscicida strains. This opposite result to the present study is not surprising, since in the present study the antigens of the pathogen were tested with antibodies having specificity against certain immunogens. In contrast, polyclonal antibodies represent a mixture of antibodies specific for a mixture of antigens, thus making the recognition of minute serological differences difficult.

Further research on ribotypes, knowledge concerning the way they influence the antigenicity of the pathogen and the ways that the ribotypes can be influenced would shed more light on the differences among strains of Ph.d.p. from various origins. This could also positively affect diagnostic and vaccine development plans for the future.

Acknowledgements. We thank Prof. G. Giorgetti, Prof. Aoki, Dr L. Kantham, Mr T. Prappas, Miss K. Lytra, Mr H. Nousias, Miss $H$. Vigneulle and $\mathrm{Mr} N$. Wajsbrot for kindly providing isolates of $P$. piscicida (Photobacterium damsela subsp. piscicida). Vassilis Bakopoulos was funded by an EC fellowship.

\section{LITERATURE CITED}

Bakopoulos V. Adams A, Richards RH (1995a) Some biochemical properties and antibiotic sensitivities of Pasteurella piscicida isolated in Greece and comparison with strains from Japan. France and Italy. J Fish Dis 18:1-7

Bakopoulos V. Adams A, Richards RH (1995b) Crossreactivity testing of anti-Pasteurella piscicida serum using ELISA and WB (poster). The Nordic Symposium on Fish Immunology, May 24-27 1995. Reykjavik, Iceland
Bakopoulos V, Adams A, Richards RH (1996) Production and characterisation of monoclonal antibodies against Pasteurella piscicida, the causative agent of fish pasteurellosis. J Fish Dis (in press)

Baudin-Laurencin F, Pepin JF, Raymond JC (1991) First observation of an epizootic of pasteurellosis in farmed and wild fish of the French Mediterranean coasts. Abstracts, European Association of Fish Pathologists, 5th International Conference, 'Diseases of Fish and Shellfish' Budapest, Hungary, 25-29 August

Ceschia G, Quaglio F, Giorgetti G, Bertoja G. Bovo G (1991) Serious outbreak of pasteurellosis (Pasteurella piscicida) in euryhaline species along the Italian coasts. Abstracts, European Association of Fish Pathologists, 5th International Conference, 'Diseases of Fish and Shellfish'. Budapest, Hungary, 25-29 August

Davies RL (1991) Clonal amalysis of Yersinia ruckeri based on biotypes, serotypes and outer membrane protein-types. J Fish Dis 14:221-228

Gauthier G, Lafay B, Ruimi R, Breittmayer V, Nicolas JL, Gauthier $M$, Christen $R$ (1995) Small subunit r-RNA sequences and whole DNA relatedness concur for the reassignment of Pasteurella piscicida (Snieszko et al.) Janssen \& Surgalla, to the genus Photobacterium as Photobacterium damsela subspecies piscicida comb. Nov. Int J Syst Bacteriol 45:139-144

Janssen WA, Surgalla MJ (1968) Morphology, physiology and serology of a Pasteurella species, pathogenic for white perch (Roccus americanus). J Bacteriol 94:1606-1610

Kubota S, Kimura M, Egusa S (1970) Studies on bacterial tuberculoidosis in cultured yellowtail-I. Symptomatology and histopathology. Fish Pathol 4:111-118

Kusuda R, Yamaoka M (1972) Etiological studies on bacterial Pseudotuberculosis in cultured yellowtail with Pasteurella piscicida as the causative agent--1. On the morphological and biochemical properties. Bull Jap Soc Scient Fish 38: $1325-1332$

Laemmli UK (1970) Cleavage of struclural proteins during the assembly of the head of bacteriophage T4. Nature 227: $680-685$

Magarinos B, Romalde JL, Bandin I, Fouz B, Toranzo AE (1992) Phenotypic, antigenic and molecular characterisation of Pasteurella piscicida strains isolated from fish. Applied Environ Microbiol 58:3316-3322

Magarinos B, Romalde JL, Barja JL. Toranzo AE (1995) Ribotyping analysis of the fish pathogen Pasteurella piscicida. Abstract, European Association of Fish Pathologists, 7th International Conference, 'Diseases of Fish and Shellfish' Palma de Mallorca, Spain, 10. 15 September 1995

Nomura J, Aoki T (1985) Morphological analysis of lipopolysaccharide from Gram (-) fish pathogenuc bacteria. Fish Pathol 20:193-197

Snieszko SF, Bullock GL, Hollis E, Boone JG (1964) Pasteurella spp. from an epizootic of white perch (Roccus americanus) in Chesapeake Bay tide water areas. J Bacteriol 88:1814-1815

Toranzo AE, Barreiro S, Casal JF, Figueras A, Magannos B, Barja JL (1991) Pasteurellosis in cultured gilthead seabream (Sparus aurata): first report in Spain. Aquaculture 99:1-15

Wiens GD. Turaga PSD, Kaatari SL (1990) Western blot analysis of a fish pathogen. In: Stolen JS, Fletcher TC, Anderson DP, Roberson BS, van Muiswinkel WB (eds) Techmques in fish immunology. SOS Publ, Fair Haven, p 87-94

Zhao J, Aoki T (19\&2) Plasmid profile analysis of Pasteurella piscicida and use of a plasmid DNA probe to identify the species. J Aquat Anim Health 4:198-202 